\title{
Alkol ve Katalizör Miktarlarının Farklı Katalizörlerle Üretilen Kanola Biyodizelinin Dönüşüm Oranı ve Yakıt Özellikleri Üzerindeki Etkisi
}

\author{
Ceyla ÖZGÜR ${ }^{* 1}$ \\ ${ }^{1}$ Çukurova Üniversitesi, Mühendislik Mimarlık Fakültesi, Otomotiv Mühendisliği Bölümü, \\ Adana
}

Geliş tarihi: 02.02.2016 Kabul tarihi: 08.03.2016

\section{Özet}

$\mathrm{Bu}$ deneysel çalışmada transesterifikasyon yöntemiyle farklı katalizör ve alkol miktarlarında sodyum hidroksit $(\mathrm{NaOH})$ ve potasyum hidroksit $(\mathrm{KOH})$ katalizörleri kullanılarak kanola biyodizeli üretilmesi amaçlanmıştır. Üretilen biyodizel örneklerinin dönüşüm oranı, viskozite, yoğunluk ve soğuk akış özellikleri ölçülmüş ve karşılaştırma yapılmıştır. Elde edilen sonuçlara göre en yüksek verim ve en düşük soğuk akış özellikleri $\mathrm{NaOH}$ kullanıldığında üretilen biyodizel de $\% 0,75$ katalizör oranı ve $6: 1$ alkol/yağ mol oranında; KOH kullanıldığında üretilen biyodizel için \%1,00 katalizör oranı ve 9:1 alkol/yağ mol oranında elde edilmiştir.

Anahtar Kelimeler: Kanola biyodizeli, Katalizör, Viskozite, Soğuk akış özellikleri

\section{The Impacts of Alcohol and Catalyst Amounts on Conversion Rate and Fuel Properties of Canola Biodiesel Produced by Using Different Catalysts}

\begin{abstract}
In this experimental study, it is aimed to produce canola biodiesel from transesterification method with different amounts of catalyst and alcohol/molar ratio by using sodium hydroxide $(\mathrm{NaOH})$ and potassium hydroxide $(\mathrm{KOH})$ as catalyst. The converison ratio, viscosity, density and cold flow properties of produced biodiesel samples were measured and compared. According to the acquired results, the highest yield and the lowest cold flow properties were obtained with $0,75 \%$ catalyst concentration and 6:1 alcohol/oil molar ratio for biodiesel production by using sodium hydroxide, 1,00\% catalyst concentration and 9:1 alcohol/oil molar ratio for biodiesel production by using potassium hydroxide.
\end{abstract}

Keywords: Canola biodiesel, Catalyst, Viscosity, Cold flow properties

\footnotetext{
* Yazışmaların yapılacağı yazar: Ceyla ÖZGÜR, Mühendislik Mimarlık Fakültesi, Otomotiv Mühendisliği Bölümü, Adana.cgungor@cu.edu.tr
} 


\section{GíRIŞ̧}

Günümüzde nüfusun her geçen gün artması ve teknolojik alanda yapılan gelişmeler enerji tüketiminde artışa yol açmaktadır bu durumda çevre kirliliğinde büyük bir rol oynamaktadır [1]. Fosil kökenli yakıtların hava kirliliğine sebep olması ve fosil yakıt rezervlerinin azalması araştırmacıları alternatif yakıt arayışına itmektedir [2]. Petrol bağımlılı̆ı̆ını azaltmak için biyodizel gibi yenilenebilir enerji kaynaklarının gelişimi çok önemlidir. Biyodizelin en önemli avantajları yenilenebilirliği, yüksek oranda biyolojik bozunabilirliği, yüksek parlama noktası ve düşük emisyon miktarlarıdır [3]. Biyodizelin pek çok avantajı bulunduğu gibi bazı dezavantajları da vardır. En önemli dezanatajlarından birisi de viskozitesinin ve soğuk akış özelliklerinin dizel yakıtına oranla daha yüksek olmasıdır [4,5]. Biyodizel kanola, soya, palm, pirinç, mikroalg, vb. pek çok yağdan elde edilebilir [6-9]. Transesterifikasyon yöntemi biyodizel üretiminde en çok tercih edilen yöntemdir. Transesterifikasyon yöntemi kullanılarak gliserin esaslı triesterlerin alkil esaslı monoesterlere dönüştürülmesi sağlanmış olur.

Transesterifikasyon reaksiyonunda, ucuz olması ve reaksiyona kolay girmesinden dolayı alkol olarak metanol kullanılır. Bu reaksiyonda katalizör olarak asidik, bazik veya enzim katalizörleri kullanılır, bazik katalizörler diğer katalizörlere oranla daha hızlı reaksiyona girdiği için daha çok tercih edilirler [10]. Metil ester dönüşüm miktarını etkileyen en önemli parametrelerden bir diğeri de alkol-yağ molar oranıdır. Stokiyometrik transesterifikasyon reaksiyonu, 1 mol gliserid ile 3 mol alkol reaksiyona girerek 3 mol yağ asidi ile 1 mol gliserol oluşturur [11].

\section{2. ÖNCEKİ ÇALIŞMALAR}

Çıldır ve Çanakçı [12] çalışmalarında ayçiçek yağı, mısırözü yağı ve kolza yağından biyodizel üretmişlerdir. Laboratuar ortamında transesterifikasyon yöntemi kullanılarak katalizör ve alkol miktarının transesterifikasyon reaksiyonu üzerindeki etkisini araştırılmışlardır. Elde edilen sonuçlara göre esterlerin dönüşüm oranları, gliserin miktarları, kinematik viskoziteleri, yoğunlukları, akma noktaları, asit numaraları ve parlama noktaları ölçülmüştür. Sonuç olarak; ayçiçek, kolza, mısırözü yağlarından elde edilen metil esterlerin, yüksek akma noktasındaki problemin giderilmesinden sonra dizel motorlarında yakıt olarak kullanılabileceği görülmüştür.

Azcan ve Danışman [13] pamuk yağından sodyum hidroksit ve potasyum hidroksit katalizörleri eşliğinde metanol ile transesterifikasyonunu incelemiştir. Gerçekleştirilen parametrik çalışmalara bağlı olarak optimum reaksiyon koşulları (reaksiyon sıcaklı̆̆ı, reaksiyon süresi, katalizör oranı) belirlenmiştir.

Chuah ve arkadaşları [14] yaptıkları çalışmada atık pişirme yağlarından biyodizel üretiminde optimum reaksiyon parametrelerini karşılaştırmışlardır. Çalışmalarında alkol/yă oranını: 1:4-1:7 aralığında, katalist miktarını ağırlıkça \%0,5-1,25 aralığında ve reaksiyon sıcaklığını $50-65^{\circ} \mathrm{C}$ aralığında değiştirmişlerdir. Sonuçlar incelendiğinde en fazla dönüşüm oranı 1:6 molar oranında \%1 katalizör miktarında $60{ }^{\circ} \mathrm{C}$ de bulunmuştur.

Tomasevic ve Marinkovic [15] çalışmalarında kızartma yağının metanolizini araştırmışlardır. Yağ/alkol oranı, katalizör miktarının, reaksiyon sıcaklık ve reaksiyon süresinin ürün verimini ve saflığnı ne şekilde etkilediğini incelemişlerdir. Elde etiikleri verilerden $\% 1$ potasyum hidroksitle $25^{\circ} \mathrm{C}$ 'e de, 1:6 yağ/alkol molar oranında, 30 dakika reaksiyon süresinde üretilen biyodizelin, dizel motorunda kullanıma uygun bir biyodizel olduğunu bulmuşlardır.

$\mathrm{Bu}$ çalışmanın amacı sodyum hidroksit $(\mathrm{NaOH})$ ve potasyum hidroksit $(\mathrm{KOH})$ katalizörleriyle üretilen kanola biyodizelinin üretimi esnasında katalizör miktarı ve alkol/yağ molar oranının metil ester dönüşüm oranı üzerine etkilerinin incelenmesi ve elde edilen biyodizellerin dizel yakıtına oranla daha yüksek olan viskozite ve soğuk akış özelliklerinin iyileştirilmesidir. 


\section{MATERYAL VE METOT}

\subsection{Materyal}

$\mathrm{Bu}$ çalışmada biyodizel transesterifikasyon yöntemi kullanılarak üretilmiştir. Biyodizel üretiminde hammadde olarak marketten elde edilen kanola yağı, alkol olarak \%99,9 saflıkta metil alkol ve katalizör olarak potasyum hidroksit $(\mathrm{KOH})$ ve sodyum hidroksit $(\mathrm{NaOH})$ kullanılmıştır.

\subsection{Metod}

Yapılan deneysel çalışmada kullanılan biyodizel kanola yağından transesterifikasyon yöntemi kullanılarak elde edilmiştir. Biyodizel üretimi sırasında katalizör olarak yağın kütlece $\% 0,25$, $0,50,0,75,1,00,1,25$ ve 1,50 oranlarında $\mathrm{NaOH}$ ve $\mathrm{KOH}$ kullanılmıştır. Ayrıca, alkol/yă mol oranı $3: 1,5: 1,6: 1$ ve 9:1 olarak değiştirilmiştir. Biyodizel üretiminde kullanılan yağ, katalizör ve alkol miktarları hassas terazide ölçülmüştür. Metanol ve katalizör ayrı bir cam kapta manyetik karıştırıcı kullanılarak karıştırılmıştır. Daha sonra bu karışım önceden $65^{\circ} \mathrm{C}$ 'ye 1sitılmış yağ içersine ilave edilerek reaksiyon başlatılmıştır. Karışım bir saat sürede 800 devir/dakika hızla karıştırılarak reaksiyon gerçekleştirilmiştir. Reaksiyon süresince sicaklık $60^{\circ} \mathrm{C}$ 'de sabit tutulmuştur. Ardından karışım bir süre ile ayırma hunisine koyulmuş bu sayede biyodizelin gliserin fazından ayrılması sağlanmıştır. Son olarakta elde edilen biyodizel 1 lik su ile y1kanmış, $105^{\circ} \mathrm{C}$ 'de bir saat kurutulduktan sonra filtreleme işlemine tabi tutulmuştur. Deneyler sonucunda elde edilen biyodizellerin viskozite, yoğunluk, akma noktası, bulutlanma noktası ve soğuk filtre tıkanma noktaları ölçülmüştür. Biyodizel üretimi ve elde edilen yakıtların yakıt özellikleri Çukurova Üniversitesi Otomotiv Mühendisliği Laboratuvarlarında gerçekleştirilmiştir. Hazırlanan biyodizellerin analizinde KEM DA130 yoğunluk ölçme cihazı, Tanaka AKV-202 kinematik viskozite ölçüm cihazı, Tanaka MPC-102 akmabulutlanma noktası tayin cihazı ve Tanaka AFP-102 soğuk filtre tıkanma noktası tayin cihazı kullanılmıştır. Elde edilen biyodizel dönüşüm oranı aşağıdaki denklem kullanılarak hesaplanmıştır [16]:

\%Dönüşüm 0ranı $=\frac{\text { Gram cinsinden üretilen metil ester miktarı }}{\text { Gram cinsinden reaksiyonda kullanilan yağ miktarı }} \times 100$

\section{BULGULAR VE TARTIŞMA}

Yapılan bu çalışmada sodyum hidroksit $(\mathrm{NaOH})$ ve potasyum hidroksit $(\mathrm{KOH})$ katalizörleri kullanılarak farklı katalizör ve alkol miktarlarında elde edilen kanola biyodizelinin dönüşüm oranı, viskozite, yoğunluk ve soğuk akış özellikleri ölçülmüştür.

\subsection{Katalizör Miktarının Transesterifikasyona Etkisi}

Deneyler esnasında katalizör miktarı yağın kütlece $\% 0,25,0,50,0,75,1,00,1,25$ ve 1,50 oranlarında değiştirilmiş olup, alkol/yağ oranı 6:1, reaksiyon sıcaklığ $160^{\circ} \mathrm{C}$ ve reaksiyon süresi 60 dakikada sabit tutulmuştur. Şekil 1'de $\mathrm{NaOH}$ ve $\mathrm{KOH}$ katalizörleri ile üretilen kanola yağ \% dönüşüm oranlarının katalizör miktarları ile değişimi verilmiştir. Elde edilen verilere göre $\mathrm{NaOH}$ katalizörü için maksimum \%94, KOH katalizörü için maksimum \%92 olduğu belirlenmiştir. Reaksiyonda kullanılan katalizör miktarı \%0,25'den \%1,00 oranına arttıça biyodizel dönüşüm oranlarınında artış gözlemlenmiştir. $\mathrm{Bu}$ da reaksiyon içerisinde katalizör bulunmasının reaksiyon oranını arttırdığının güçlü bir kanıtıdır. Ne var ki $\% 1$ katalizör miktarından sonra dönüşüm oranlarında önemli bir düşüş görülmektedir. Bunun nedeni de \%1'den yüksek miktarda katalizör oranında sabunlaşmanın meydana gelmesi ve bu sebeple biyodizel verimin azalmasi olarak yorumlanmaktadır [14,17]. Şekil 2'de $\mathrm{NaOH}$ ve $\mathrm{KOH}$ katalizörleri ile üretilen kanola biyodizellerinin \% katalizör miktarları göz önünde bulundurularak viskozitelerindeki değişim verilmiştir. Elde edilen verilere göre $\mathrm{KOH}$ kullanımında \%1,00 katalizör oranında ve $\mathrm{NaOH}$ kullanımında ise \%0,75 katalizör oranında en 


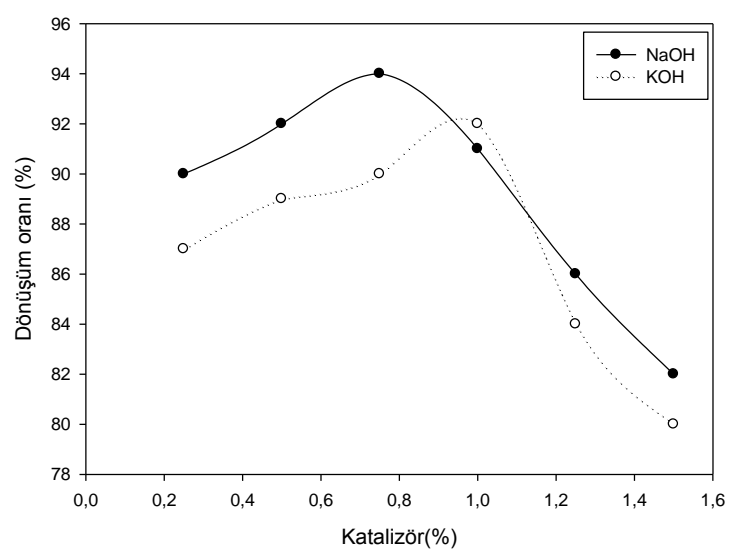

Şekil 1. Katalizör miktarının dönüşüm oranı üzerine etkisi

düşük viskozite değerleri ölçülmüştür. Daha önce yapılan çalışmalar incelendiğinde biyodizel veriminin artmasının viskoziteyi azalttığ gözlemlenmiştir ve optimum katalizör miktarından sonra sabunlaşmanın meydana gelmesi biyodizel verimini azalttığından dolayı viskozitenin artışına sebep olmaktadır $[5,17]$.

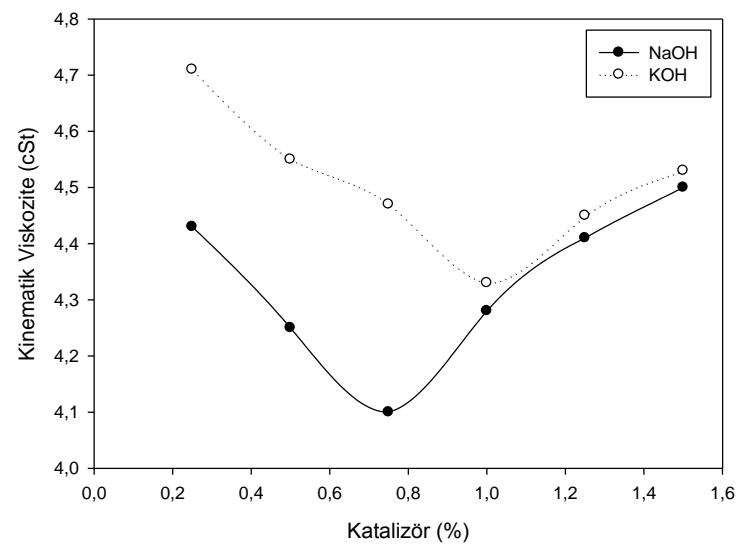

Şekil 2. Katalizör miktarının kinematik viskozite üzerindeki etkisi

Şekil 3'de görüldüğü üzere düşük katalizör miktarlarında yoğunluk düşük iken katalizör miktarı arttıkça yoğunluğun arttığı belirlenmiştir. $\mathrm{KOH}$ kullanımında \%1,00 katalizör oranında $0,884 \mathrm{~g} / \mathrm{ml}, \mathrm{NaOH}$ kullanımında ise $\% 0,75$ katalizör oranında $0,882 \mathrm{~g} / \mathrm{ml}$ ile en düşük yoğunluk değerleri elde edilmiştir.

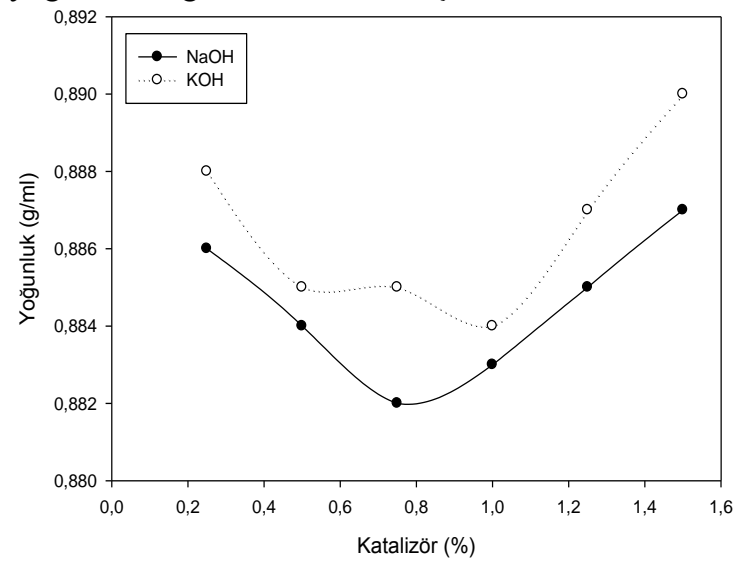

Şekil 3. Katalizör miktarının yoğunluk üzerindeki etkisi

Katalizör miktarının soğuk akış özellikleri üzerindeki etkileri sırasıyla Şekil 4, Şekil 5 ve Şekil 6'da verilmiştir. Şekil 4, 5 ve 6 incelendiğinde katalizör miktarı arttıkça soğuk akış özelliklerinin düştüğü optimum katalizör miktarına geldikten sonra ise soğuk özelliklerinin arttığ1 gözlemlenmiştir.

Özellikle katalizör miktarı \%1,25 ve 1,50'de soğuk akış özelliklerinde önemli bir ölçüde artış görülmüş olup bunun nedeni yüksek katalizör oranlarında reaksiyonun tamamlanmamasıdır [18].

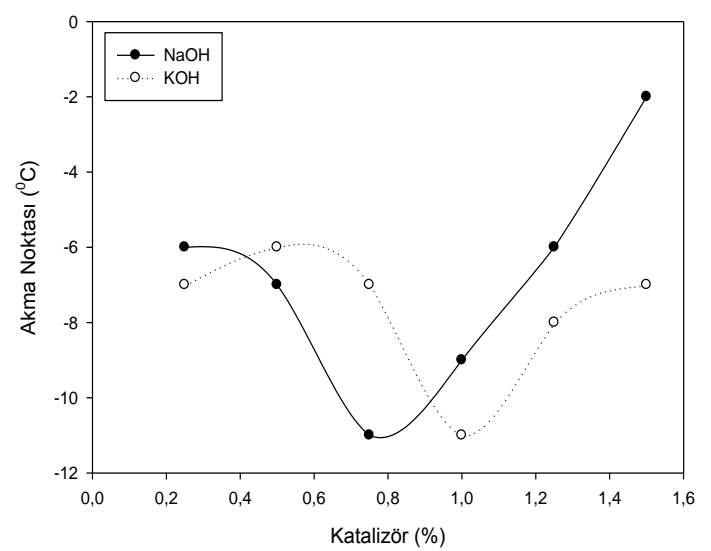

Şekil 4. Katalizör miktarının akma noktası üzerindeki etkisi 


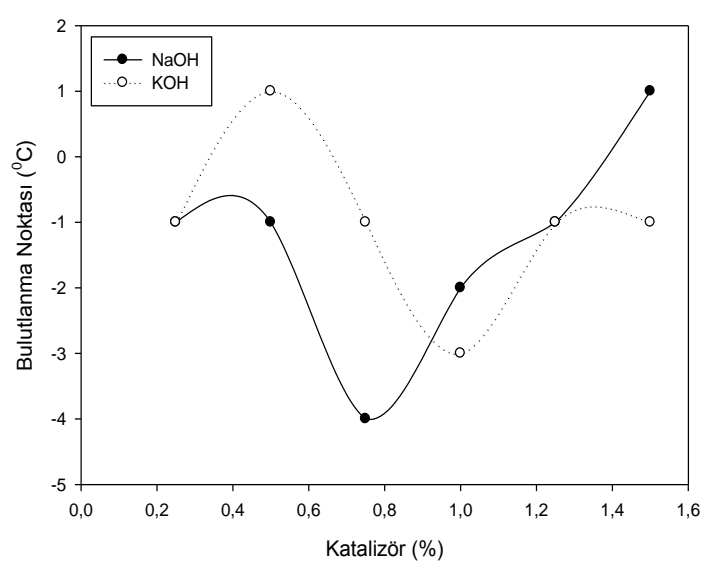

Şekil 5. Katalizör miktarının bulutlanma noktası üzerindeki etkisi

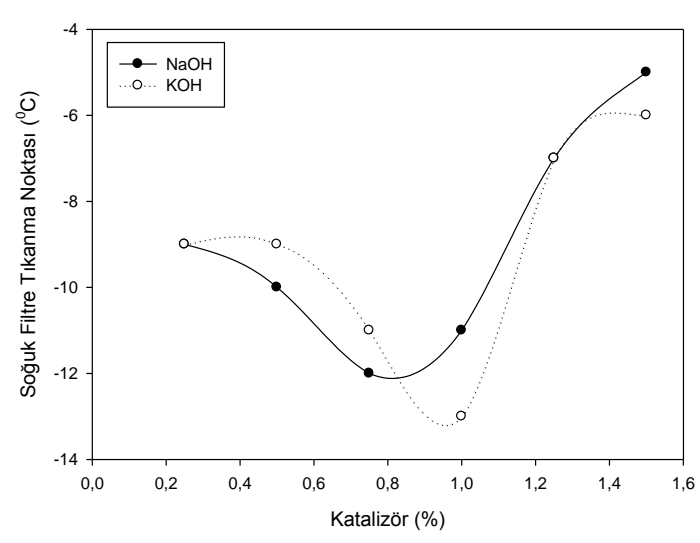

Şekil 6. Katalizör miktarının soğuk filtre tıkanma noktası üzerindeki etkisi

\subsection{Alkol/Yağ Oranının Transesterifikasyona Etkisi}

Metil ester dönüşümünü etkileyen en önemli etkenlerden bir tanesi de alkol/yağ molar oranıdır [14]. Yapılan çalışmada alkol/yăg oranı 3:1, 5:1, 6:1 ve 9:1 oranlarında değiştirilmiş olup, katalizör miktarı $\mathrm{NaOH}$ katalizörü için \% 0,75 oranında, $\mathrm{KOH}$ katalizörü için \%1.00 oranında, reaksiyon sicaklığ $160^{\circ} \mathrm{C}$ ve reaksiyon süresi 60 dakikada sabit tutulmuştur. Şekil 7'de $\mathrm{NaOH}$ ve $\mathrm{KOH}$ katalizörleri ile üretilen kanola yağ \%dönüşüm oranlarının alkol/yağ oranı ile değişimi verilmiştir. Şekil 7 incelendiği zaman $\mathrm{NaOH}$ katalizörü için maksimum dönüşüm miktarı 6:1 alkol/yăg oranında \%94 olarak, $\mathrm{KOH}$ katalizörü için maksimum dönüşüm miktarı 9:1 alkol/yağ oranında $\% 93$ olarak belirlenmiştir. Transesterifikasyon reaksiyonunda fazla miktarda alkol kullanıldığında ester faz ile gliserin fazın ayrıştırılması zor olduğundan çözünürlük içerisinde bir miktar gliserin kalır. Çözelti içerisinde gliserin kalması reaksiyonun yönünü girenler yönüne kaydıracağından reaksiyon verimi de düşer $[5,19]$.

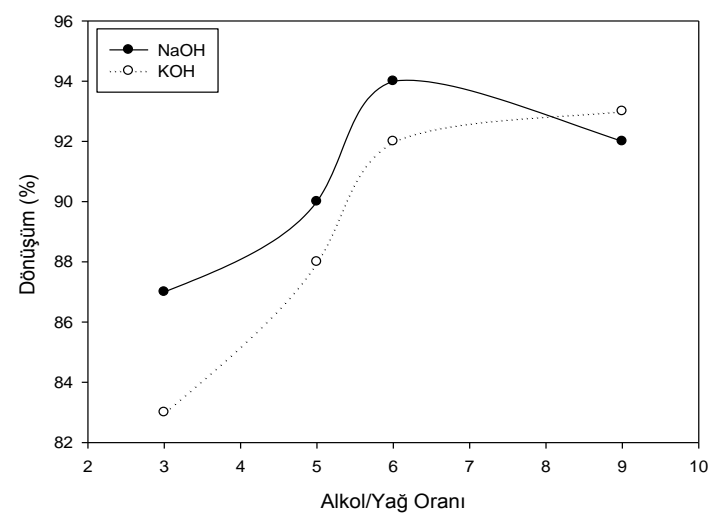

Şekil 7. Alkol/yağ oranının dönüşüm oranı üzerine etkisi

Şekil 8 ve Şekil 9'da alkol/yağ oranının $\mathrm{NaOH}$ ve $\mathrm{KOH}$ katalizörleri ile üretilen kanola biyodizellerinin viskoziteleri ve yoğunlukları üzerindeki değişimleri verilmiştir. Elde edilen veriler incelendiğinde optimum alkol/yağ oranına ulaşılana kadar kinematik viskozitenin azaldığı, daha sonra arttığ 1 belirlenmiştir. $\mathrm{NaOH}$ katalizörü için 6:1 mol oranında 4,1 cSt, KOH katalizörü için 9:1 oranında 4,28 cSt ile en düşük kinematik viskozite değerlerine ulaşılmıştır.

Alkol/yağ oranının soğuk akış özellikleri üzerindeki etkileri sırasıyla Şekil 10, Şekil 11 ve Şekil 12'de verilmiştir. Elde edilen sonuçlara göre reaksiyon içerisindeki alkol oranı arttıkça soğuk akış özelliklerinde bir yükseliş görülmektedir. En düşük soğuk akış özellikleri 6:1 ve 9:1 alkol/yağ molar oranlarında saptanmıştır. 


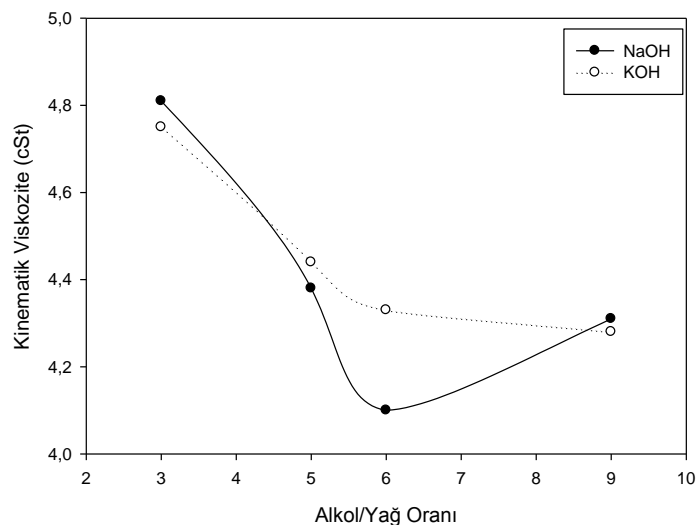

Şekil 8. Alkol/yağ oranının kinematik viskozite üzerindeki etkisi

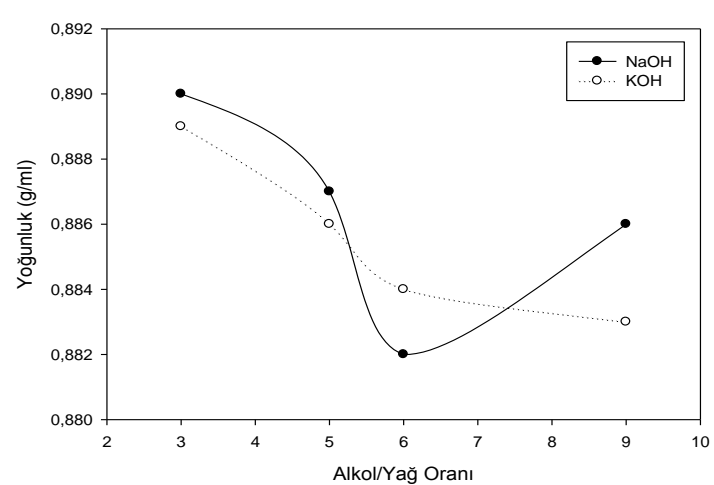

Şekil 9. Alkol/yağ oranının yoğunluk üzerindeki etkisi

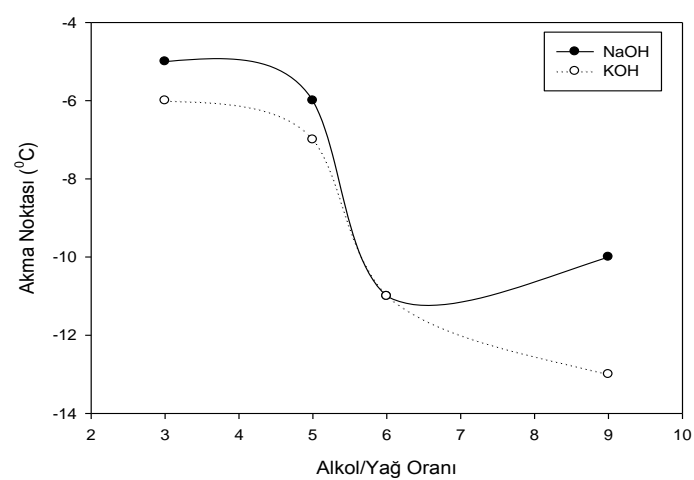

Şekil 10. Alkol/yağ oranının akma noktası üzerindeki etkisi

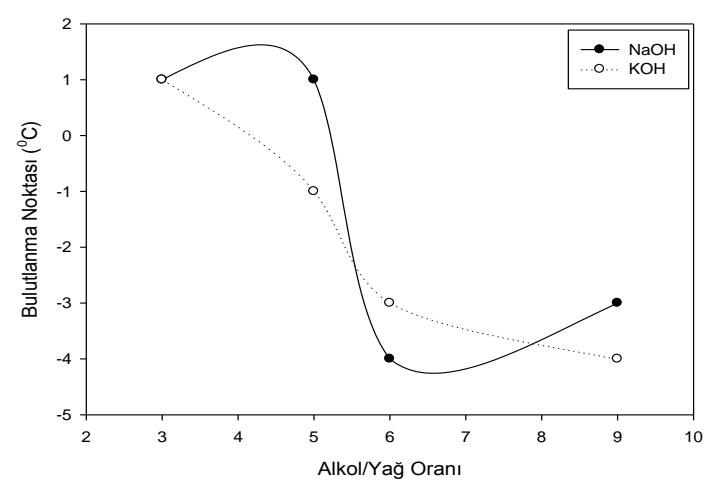

Şekil 11. Alkol/yağ oranının bulutlanma noktası üzerindeki etkisi

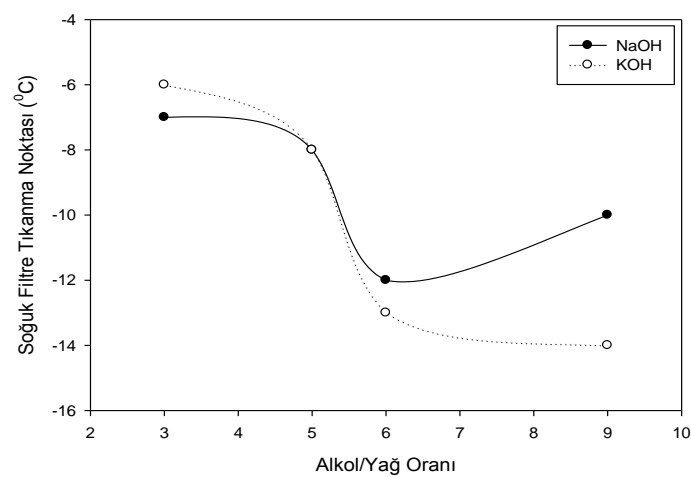

Şekil 12. Alkol/yağ oranının soğuk filtre tıkanma noktası üzerindeki etkisi

\section{SONUÇLAR}

Yapılan deneysel çalışmada farklı katalizörlerle üretilen kanola biyodizelinin üretim sürecinde katalizör miktarının ve alkol/yağ molar oranının metil ester dönüşüm oranı ve yakıt özellikleri üzerindeki etkisi araştırılmıştır. Deneysel çalışma sonuçları aşağıda özetlenmiştir:

En yüksek metil ester dönüşüm oranı $\mathrm{NaOH}$ katalizörü kullanılarak üretilen biyodizel için $\% 0,75$ katalizör oranı ve 6:1 alkol/yağ mol oranında \%94; KOH katalizörü kullanılarak üretilen biyodizel için \%1,00 katalizör oranı ve 9:1 alkol/yağ mol oranında \%93 olarak ölçülmüştür. 
Transesterifikasyon yöntemiyle $\mathrm{NaOH}$ katalizörü kullanılarak üretilen biyodizel için en düşük viskozite değeri $\% 0,75$ katalizör oranı ve $6: 1$ alkol/yağ mol oranında; $\mathrm{KOH}$ katalizörü kullanılarak üretilen biyodizel için \%1,00 katalizör oranı ve 9:1 alkol/yağ mol oranında elde edilmiştir.

En düşük soğuk akış özelliklerini veren katalizör ve alkol miktarlarında $\mathrm{NaOH}$ katalizörü ile üretilen biyodizel için akma noktası -11, bulutlanma noktası -4 ve soğuk filtre tıkanma noktası -12 olarak, $\mathrm{KOH}$ katalizörü ile üretilen biyodizel için de akma noktası -13 , bulutlanma noktası -4 ve soğuk filtre tıkanma noktası -14 olarak ölçülmüştür.

\section{KAYNAKLAR}

1. Çelik, M., Solmaz, H., Yücesu, H.S., 2015. Pamuk Metil Esterine N-Heptan Katkısının Motor Performansi ve Yanma Karakteristiklerine Etkilerinin İncelenmesi, Gazi Üniv. Müh. Mim. Fak. Der., 30(3):361369.

2. Aktaş, A., Sekmen, Y., 2008. Biyodizel ile Çalışan bir Dizel Motorda Yakıt Püskürtme Avansının Performans ve Egzoz Emisyonlarına Etkisi, Gazi Üniv. Müh. Mim. Fak. Der., 23(1):199-206.

3. Shah, M., Ali, S., Tariq, M., Khalid, N., Ahmad, F., Khan, M.A., 2014. Catalytic Conversion of Jojoba Oil into Biodiesel by Organotin Catalysts, Spectroscopic and Chromatographic Characterization, Fuel, 118:392-397.

4. Boshui, C., Yuqiu, S., Jianhua, F., Jiu, W., Jiang, W., 2010. Effect of Cold Flow Improvers on Flow Properties of Soybean Biodiesel, Biomass and Bioenergy, 34:13091313.

5. Gülüm, M., Bilgin, A., Çakmak, A., 2015. Sodyum Hidroksit (Naoh) ve Potasyum Hidroksit (KOH) Kullanılarak Üretilen Misır Yağ1 Biyodizellerinin Optimum Reaksiyon Parametrelerinin Karşılaştırılması, Gazi Üniv. Müh. Mim. Fak. Der., 30(3):503-511.
6. Valente, O.S., Silva, M.J., Pasa, V.M.D., Belchior, C.R.P., Sodre, J.R., 2010. Fuel Consumption and Emissions from a Diesel Power Generator Fuelled with Castor Oil and Soybean biodiesel, Fuel, (89):3637-3642.

7. Benjumea, P., Agudelo, J., Agudelo, A., 2008. Basic Properties of Palm Oil Biodiesel-Diesel Blends, Fuel, 87:2069-2075.

8. Evangelista, J.P.C., Chellappa, T., Coriolano, A.C.F., Fernandes Jr., V.J., Souza, L.D., Araujo, A.S., 2012. Synthesis of Alumina Impregnated with Potassium Iodide Catalyst for Biodiesel Production from Rice Bran Oil, Fuel Processing Technology, 104:90-95.

9. Tüccar, G., Aydın, K., 2013. Evaluation of Methyl Ester of Microalgae Oil as Fuel in a Diesel Engine, Fuel, 112:203-207.

10. Karabaş, H., 2013. Ayçiçek Yağı Biyodizelinin Ester Dönüşüm Oranı Üzerine Etkili Olan Parametrelerin Optimizasyonu, Adnan Menderes Üniversitesi Ziraat Fakültesi Dergisi, 10(1):1-5.

11. Kafadar, A.B., 2010. Yağlardan Biyodizel Eldesine Etki Eden Faktörlerin Araştırılması, Doktora Tezi, Dicle Üniversitesi.

12. Çıldır, O., Çanakçı, M., 2006. Çeşitli Bitkisel Yağlardan Biyodizel Üretiminde Katalizör ve Alkol Miktarının Yakıt Özellikleri Üzerine Etkisinin İncelenmesi, Gazi Üniv. Müh. Mim. Fak. Der. Cilt 21, No 2, 367-372.

13. Azcan, N., Danışman, A., 2006. Pamuk Yağından Transesterifikasyon ile Biyodizel Eldesi. Yedinci Ulusal Kimya Mühendisliği Kongresi, Anadolu Üniversitesi, Eskişehir, 5-8 Eylül.

14. Chuah, L.F., Yusup, S., Aziz, A.R.A., Bokhari, A., Klemeš, J.J., Abdullah, M.H., 2015. Intensification of biodiesel synthesis From Waste Cooking Oil (Palm Olein) in a Hydrodynamic Cavitation Reactor: Effect of Operating Parameters on Methyl Ester Conversion, Chemical Engineering and Processing, 95:235-240.

15. Tomasevic, A.V., Marinkovic, S.S.; 2003. Methanolysis of Used Frying Oils, Fuel Process Technology, 81:16.

16. Altaie, M.A.H., Janius, R.B., Rashid, U., Yap, Y.H.T., Yunus, R., 2015. Cold Flow and Fuel 
Alkol ve Katalizör Miktarlarının Farklı Katalizörlerle Üretilen Kanola Biyodizelinin Dönüşüm Oranı ve Yakıt Özellikleri Üzerindeki Etkisi

Properties of Methyl Oleate and Palm-Oil Methyl Ester Blends, Fuel, 160:238-244.

17. Gülüm, M., Bilgin, A., 2014. Çeşitli Üretim Parametrelerinin $\mathrm{NaOH}$ Kullanılarak Üretilen Misır Yağı Biyodizelinin Bazı Yakıt Özelliklere Etkisi, 7. Otomotiv Teknolojileri Kongresi, Bursa, 26-27 Mayis.

18. Rasimoglu, N., Temur, H., 2014. Cold Flow Properties of Biodiesel Obtained from Corn Oil, Energy, 68:57-60.

19. Meher, L.C., Vidya Sagar, D., Naik, S.N., 2006. Technical Aspects of Biodiesel Production by Transesterification-a Review, Renewable and Sustainable Energy Reviews, 10:248-268. 